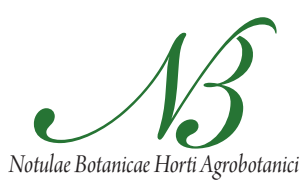

Cluj-Napoca

\title{
On the Occurence in Romania of Potentillo albae-Quercetum petraeae Libbert 1933 Association
}

\author{
Adrian INDREICA \\ Transilvania University of Brasov, Faculty of Silviculture and Forest Engineering, 1 Sirul Beethoven, \\ 500123 Brasov,Romania; adrianindreica@unitbv.ro
}

\begin{abstract}
The paper presents a plant community of dry-mesic oak forests that is new to Romania, Potentillo albae-Quercetum petraeae Libbert 1933. This association belongs to Quercion petraeae alliance and its range extends over the subcontinental area of Central Europe. A multivariate analysis (cluster analysis, non-metric multidimensional scaling ordination) of a large phytosociological database was used to identify diagnostic species, interspecific associations and the gradient of species composition. Based on species composition and site parameters, a group of relevees in oak forests that correspond to the diagnosis of Potentillo-Quercetum was identified. The Romanian relevees corresponding to this association were previously assigned, pro parte, to Carici montanae-Quercetum Gergely 1962 and Quercetum robori-petraeae Borza 1959. The relations with these and other potentially related two associations, Genisto tinctoriaeQuercetum petraeae Klika 1932 and Quercetum petraeae-cerris Soó 1963, are discussed. The vegetation and site conditions of the Potentillo albae-Quercetum association in Romania are illustrated in a phytosociological table with 25 relevees and a distribution map is provided.
\end{abstract}

Keywords: multivariate analysis, oak forests, plant communities, syntaxonomy

\section{Introduction}

In 1962 Gergely described the association Carici montanae-Quercetum petraeae from Trascau Mountains (western part of Transylvanian basin, Romania). He noticed the resemblance with the Central European association Potentillo albae-Quercetum Libbert 1933, but stated that the phytocoenoses from Trascau Mt. are different because of the presence of Carex montana and some leguminous species and the absence of spontaneous Turkey oak (considered a specific taxon for the last association, based on the works of Hungarian and Austrian authors). Yet, he asserted that Potentillo albae-Quercetum is present in the Transylvanian Plain, in the area of mixed forests with sessile oak (Quercus petraea) and Turkey oak (Quercus cerris). Since then no other references to this association have been made and no description of the syntaxon was provided for Romania. Forests of sessile oak and Carex montana, regarded as association or subassociation to Genisto tinctoriae-Quercetum petraeae Klika 1932, were reported in the Huedin basin (Csüros et al., 1969), the mountains around Brasov-south-eastern Transylvania (Danciu, 1972; Kovacs, 1979). Ularu (1972) described a Carex montana variant of Quercetum robori-petraeae Borza 1959. In the recent Romanian syntaxonomic works (Coldea and Pop, 1996; Kovacs, 2004; Sanda et al., 2001, 2008) neither Carici montanae-Quercetum nor Potentillo-Quercetum were taken into account.
Potentillo albae-Quercetum petraeae is a zonal association of Central Europe, with subcontinental-sarmatic range, including dry-mesic forests dominated by Quercus petraea or Quercus robur, developed on soils with imperfect drainage (i.e. stagnosols). It is present in Poland (Libbert, 1933; Matuskiewicz and Kozlowska, 1991), Czech Republic (Mráz, 1958; Neuhäusl and Neuhäuslová, 1968; Chytrý, 1997; Chytrý and Horak, 1997), Slovakia (Chytrý, 1994; Roleček, 2005), Germany (Müller, 1992) and Russia (Mráz, 1958; Morozova, 2003). It is also encountered in France (Treiber and Remmert, 1998). Similar communities may exist in Hungary and Austria, but their relation with Potentillo-Quercetum has not been clarified yet (Wallnofer et al., 1993; Chytrý, 1997; Roleček, 2005). In these circumstances the spread of the association southward, in Romania may be questionable.

Considering the phytosociological information gathered since the Gergely's publication (Gergely, 1962) and the statistical tools available nowadays, the aim of this study is to investigate the syntaxonomical position of oak forests with Carex montana and the hypothesis regarding the presence of Potentillo albae-Quercetum in Romania. This endeavor is also important in the context of the nowadays efforts towards sustainable forest management and conservation of all representative forest ecosystems from Romania (Donita and Biris, 2003; Abrudan et al., 2009; Ioras et al., 2009; Stancioiu et al., 2010). 
298

\section{Materials and methods}

This study is based on the analysis of a database for over 1400 relevees stored in TURBOVEG (Hennekens and Schaminée, 2001) corresponding to oak forests from Romania. The relevees were sampled according to BraunBlanquet methodology and originate partly from literature (801) and partly from our field work (610). In order to have an accurate image of the gradient in species composition, methods of numerical analysis were applied. Firstly, from the entire database only those relevees having the dominants Quercus petraea, Q. robur or Q. cerris were kept. Out of these, dry-mesic oak forests relevees were selected based on the results of the cluster analysis: the clusters with diagnostic species common for oak-hornbeam forests (Carpinion) or thermophilous forests (Quercion frainetto) were eliminated. Finally 105 relevees were selected. The analysis was performed using: the presence-absence data for species cover (in order to diminish the inconstancy in the assessment of species cover by different authors), the Sørensen coefficient for the similarity between relevees and the linkage method of flexible beta $(\beta=-0.25$, a value verified as giving the best results (McCune et al., 2002)). The optimal number of clusters corresponds to the maximum crispness value (Botta-Dukát et al., 2005). For measuring the species' fidelity the phi coefficient was used, with the cut off value of 0.30 (Chytrý et al., 2002; Willner et al., 2009). To visualize de variation between the clusters identified by the classification, the selected relevees were ordinated by the means of the non-metric multidimensional scaling (NMS) method. The distances between relevees in the floristic space were calculated by the mean of Sørensen dissimilarity, for presence-absence data. The arrangement of phytosociological tables and calculation of species fidelity were performed using the JUICE software (Tichý, 2002), and the classification and ordination of relevees by using PC-ORD (McCune and Mefford, 2006).

The selected Romanian relevees were compared with the original diagnosis of Potentillo albae-Quercetum (Libbert, 1933) and with recent descriptions of the association provided in some synthetic phytosociological studies (Mráz, 1958; Matuskiewicz and Kozlowska, 1991; Mül- ler, 1992; Chytrý, 1997; Roleček, 2005, 2007), taking into account the diagnostic species, the site conditions and the similarity of the overall species composition. Other syntaxa accounted for comparison are Genisto tinctoriaeQuercetum Klika 1932 and Quercetum petraeae-cerris Soó 1963 , as these associations were considered in the published literature as being linked with Carici montanaeQuercetum and Potentillo albae-Quercetum respectively.

The concept of broad species was used in the case of the genera Quercus (Q. petraea s.l. $=$ Q. petraea s.str., Q. dalechampii, Q. polycarpa; Q. robur s.l. $=$ Q. robur s.str., Q.pedunculiflora), Molinia (M. caerulea s.l. = M. caerulea s.str., M. arundinacea) and Dactylis (Dactylis glomerata s.l. $=$ D. glomerata, D. polygama). The nomenclature of species follows Ciocarlan (2000).

\section{Results and discussion}

The cluster analysis of the 105 selected relevees of drymesic oak forests from Romania leads to the separation of three clusters, as it is indicated by the crispness function of classification in JUICE. The first ten diagnostic species and their fidelity for each cluster are presented in Tab. 1. The species resulted as diagnostic for clusters are also convergent in the ecological and sociological meanings (verified by interspecific associations in JUICE), therefore the solution could be ecologically accepted (i.e. it is not just a statistical evidence). Two clusters correspond to the well known associations Genisto tinctoriae-Quercetum petraeae Klika 1932 (Cluster 2) and Quercetum petraeae-cerris Soó 1963 (Cluster 3) respectively.

The Cluster 1 is intuitively similar to Potentillo albaeQuercetum Libbert 1933 and the arguments for this classification are given below.

(i) Among the 43 diagnostic species for Cluster 1 almost all of the species found as diagnostic for this association in Central Europe, by different phytosociologists are included. In each region (country) there are some specific taxa, like Fragaria moschata in Czech and Slovak relevees, and Pulmonaria angustifolia in Polish relevees. Other species, like Melampyrum nemorosum or Galium sylvaticum are replaced in Romania by their ecologically similar taxa-

Tab. 1. Diagnostic species and the cluster fidelity $\left(\Phi_{\mathrm{x}} 100\right)$ for the dry-mesic oak forests in Romania

\begin{tabular}{|c|c|c|}
\hline Cluster 1 & Cluster 2 & Cluster 3 \\
\hline Potentilla alba 82.1 & Deschampsia flexuosa 76.2 & Quercus cerris 65.3 \\
\hline Stachys officinalis 79.4 & Genista ovata 54.4 & Silene viridiflora 44.5 \\
\hline Pulmonaria mollis 72.3 & Vaccinium myrtillus 53.5 & Fragaria viridis 43.0 \\
\hline Serratula tinctoria 71.3 & Luzula luzuloides 49.0 & Helleborus odorus 36.7 \\
\hline Carex montana 67.7 & Cytisus nigricans 46.4 & Euphorbia amygdaloides 35.6 \\
\hline Melittis melissophyllum 63.3 & Hieracium sabaudum 42.8 & Polygonum convolvulus 35.0 \\
\hline Convallaria majalis 55.9 & Polypodium vulgare 37.1 & Carex pairae 35.0 \\
\hline Trifolium alpestre 55.9 & Fagus sylvatica 33.2 & Potentilla micrantha 34.7 \\
\hline Quercus robur 52.0 & Betula pendula 28.7 & Melica uniflora 32.6 \\
\hline Ranunculus polyanthemos 36. & & Genista tinctoria 31.9 \\
\hline
\end{tabular}


Melampyrum bihariense and Galium schultesii respectively. The absence of such species does not affect the association's validation. The Romanian relevees include several species with regional distribution: Iris ruthenica, Phyteuma tetramerum, Crocus banaticus, Melampyrum bihariense, Helleborus purpurascens, Lathyrus transsilvanicus. Considering the concept of association in a broader sense, such elements could eventually represent differential species for a local subassociation.

(ii) There are similarities regarding ecological groups of species. One characteristic of the association is the mixture of xerophytes, mesophytes and acidophytes. The differences compared to acidic oak forests are, firstly, the species of intermittently wet and heavy soils-some of them common in meadows of Molinion alliance (Potentilla alba, Serratula tinctoria, Carex pallescens, Succisa pratensis, Ranunculus polyanthemos, Carex montana, Potentilla erecta, Poa angustifolia, Molinia caerulea agg., etc.). Secondly, the presence of eu-mesotrophic species of oak-hornbeam forests (like Stellaria holostea, Galium schultesii, Carpinus betulus) indicates more favorable ionic and mineral properties of the soil as compared to the case of acidic forests. The occurrence of acidophilous species (Luzula luzuloides, Calamagrostis arundinacea, Pteridium aquilinum, Veronica officinalis, Hieracium murorum, Genista tinctoria, Vaccinium myrtillus etc.) is in consensus with the descriptions published until now (Matuskiewicz and Kozlowska, 1991; Chytrý, 1997; Roleček, 2005, 2007). For example, Luzula luzuloides is also present in the Central European relevees of Potentillo-Quercetum with frequencies of up to $47 \%$ and cover indices of 3 . This species was found to be diagnostic, in the context of dry-mesic forests, for the alliance (Chytrý, 1997) or even for the association (Roleček, 2005). Moreover, the poor development of the moss layer and the higher number of species in phytocoenoses are arguments for not including these forests into Genisto tinctoriae-Quercetum. On the other hand, the differences against thermophilous associations consist of the cooler, more humid and poorer sites, located in the area of the mesic forests, thus corresponding with the significance of Quercion petraeae alliance-more humid and slightly cooler than Quercion pubescenti-petraeae or Aceri tatariciQuercion (Jakucs, 1960; Chytrý and Horak, 1997). The studied forests are located outside of the optimal range of thermophilous oaks, Q. frainetto, Q.pubescens or Q.pedunculiflora, therefore the species of Quercion frainetto or Aceri tatarici-Quercion are missing.

(iii) The subboreal species (Vaccinium sp., Pyrola sp.), present in Romanian relevees, are considered (Wallnöfer $e t$ al., 1993) as a major trait for Potentillo-Quercetum, against peri-pannonian Quercetum petraeae-cerris. Even Norway spruce (Picea abies) occurs, partly due to natural causes, inside or close to the sessile oak stands in south-eastern Transylvania - reflecting also the continental nuances of the climate.

(iv) The ecological conditions are equivalent with those from the Central European range of the association. The most peculiar is the imperfect drainage of the soil. The higher elevation of Romanian phytocoenoses compensates the southern latitude while the Carpathian arch reduces the submediterranean influences from the south and the continental ones from the east. A curious analogy makes reference to the distribution in the peripheral areas of watersheds (Libbert, 1933; Roleček, 2005).

(v) Certain connections with Central European drymesic oak forests on heavy soils are given by some relict species of natural old forests, like Festuca amethystina and

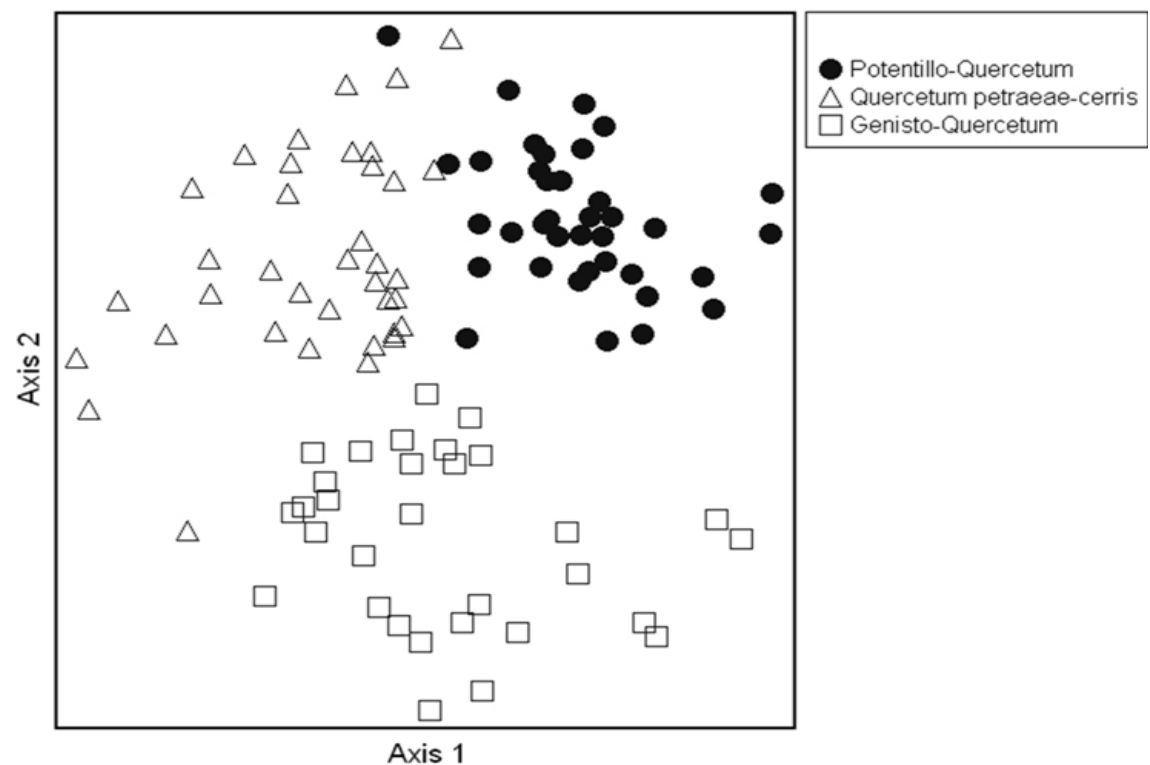

Fig. 1. NMS ordination of dry-mesic oak forests on heavy soils (Potentillo-Quercetum), acidic forests (Genisto-Quercetum) and Turkey oak forests (Quercetum petraeae-cerris) in Romania 
300

Adenophora liliifolia (Wallnöfer, 2003; Roleček, 2004, 2007; Ciosek, 2006; Indreica, 2007).

The NMS ordination of dry-mesic oak forests of Romania shows a clear separation of the three clusters (Fig. 1). The first 2 axes jointly explain $70 \%$ of the variation of floristic composition in the original $\mathrm{n}$-dimensional space.

The relevees of the first cluster were originally assigned by their authors either to Carici montanae-Quercetum Gergely 1962 (Gergely, 1962; Danciu, 1972), Quercetum robori-petraeae Borza (1928, 1959; relevees of Borza, 1959; Ciurchea, 1965; Ularu, 1972; Coldea and Miclaus, 1975), Melampyro bihariensis-Carpinetum (Borza, 1941) Soó 1964 em. Coldea (1975) or to Carpino-Quercetum cerris Klika (1938), (some of the relevees of Pop and Coldea, 1987). Most of the relevees of oak forests with Carex montana fall into the definition of Potentillo-Quercetum. In some cases Carex montana may reach high cover on xeric-oligotrophic sites, in transitional communities towards Genisto tinctoriae-Quercetum, but this syntaxon could be easily recognized by site physiography (moderately to steep slopes, shallow and skeletal soil) and the lower number of species. Another association considerably linked to Potentillo-Quercetum, but not identical, is Quercetum robori-petraeae. This was originally defined (Borza, 1959; Soó, 1951) as xeric association, but in time its meaning became too heterogeneous: nowadays it is included in Genisto germanicae-Quercion Neuhäusl et NeuhäuslováNovotná (1967), although many relevees correspond to oak-hornbeam forests.

In order to describe the vegetation and site conditions of Potentillo albae-Quercetum in Romania, 25 relevees sampled during 2005-2010 were selected and presented in Tab. 2.

Diagnostic species: Potentilla alba, Stachys officinalis, Serratula tinctoria, Pulmonaria mollis, Carex montana, Carexpallescens, Euphorbia angulata, Hierochloë australis, Laserpitium prutenicum.

Constant species: Quercus petraea, Fragaria vesca, Cruciata glabra, Veronica chamaedrys, Carex montana, Potentilla alba, Serratula tinctoria, Luzula luzuloides, Trifolium medium, Viola reichenbachiana, Lathyrus niger, Vincetoxicum hirundinaria, Clinopodium vulgare, Calamagrostis arundinacea etc.

Dominant species: Quercus petraea, Carex montana, Quercus robur, Pteridium aquilinum, Pulmonaria mollis.

The tree layer's coverage is of 50-80\%, Quercus petraea, Q. robur or, in the western part of Transylvanian basin, Quercus cerris prevailing. Trees of Fagus sylvatica, Populus tremula or Pinus sylvestris participate in the stand composition only in rare cases. In the shrub layer, which is rather sparse, the most frequent species are Crataegus monogyna, Carpinus betulus, Corylus avellana, Pyrus pyraster, Frangula alnus, Rosa gallica, $R$. canina etc. The herbaceous layer is well developed, covering $40-80 \%$, and is very rich in species. The average number of taxa per relevee is 60-70 and the maximum values reach 90-98 taxa/relevee. The moss layer is absent or very poor, being represented by Atrichum undulatum, Polytrichum formosum and Hypnum cupressiforme.

These forests are developed on flysh, paleogenic sediments (marls and calcareous sandstones), volcanic sediments, limestone or conglomerates, at altitudes between

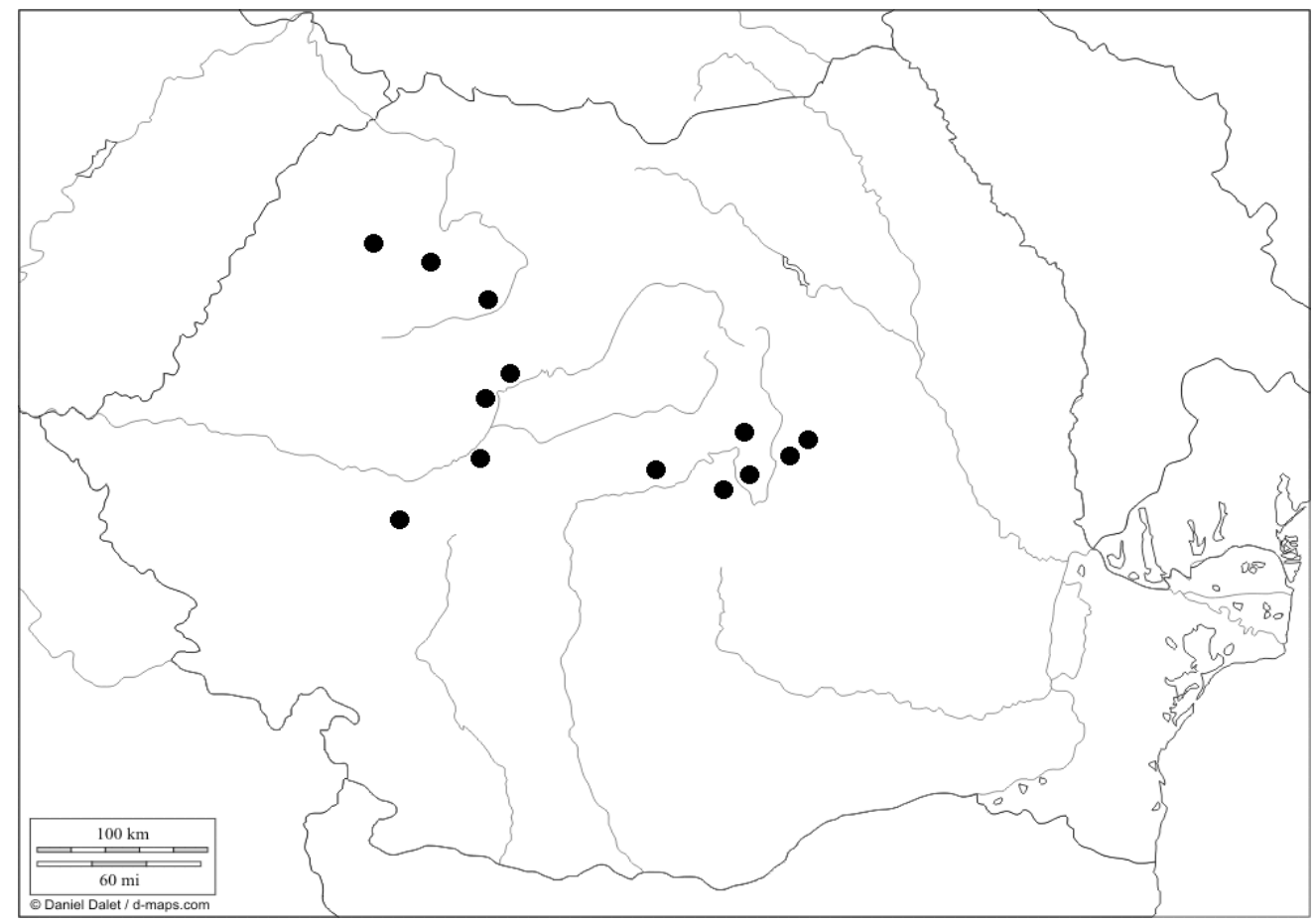

Fig. 2. Distribution of the Potentillo albae-Quercetum association in Romania 
400-800 m, on the upper part of the slopes, on plane or gently inclined surfaces. The soils are slightly to moderately acidic $(\mathrm{pH}=4.6-5.3)$, with stagnic properties due to the higher proportion of clay in the $\mathrm{B}$ horizon. The mean annual temperature is $7-8^{\circ} \mathrm{C}$ and the mean annual rainfall is $550-650 \mathrm{~mm}$. The continentality index $\left(\mathrm{I}_{\mathrm{c}}=\mathrm{T}_{\max }-\mathrm{T}_{\min }\right)$ is between 22 and 23 , indicating a subcontinental climate.

The range of the Potentillo albae-Quercetum association in Romania extends around the Transylvanian basin, including the peripherial basins of Brasov and Hateg. The respective forests were found in the administrative range of the following localities (Fig. 2): Racas (Salaj county), ClujNapoca, Cheia (Cluj county), Aiud, Sebes (Alba county), Hateg (Hunedoara county), Boholt (Brasov county), Aita, Belani, Biborteni, Batani, Doboseni, Haghig, Herculian, Lemnia, Malnas, Petriceni, Racos, Varghis (Covasna county) and Plaiesi (Harghita county).

\section{Conclusions}

Both intuitively and by statistical analysis (classification and ordination methods, fidelity measure and interspecific associations) it is demonstrated that Potentillo albae-Quercetum Libbert 1933 association is present in Romania. This syntaxon is confined to specific site conditions-the same as in its known range and indicated by the similar group of diagnostic species, it poses a high floristic diversity and could be clearly distinguished from other related associations. Its extent to the south is possible due to the climatic compensations of the higher altitudinal sites and the "shadow" provided by basins. This paper contributes to the knowledge on the distribution and variability of the Potentillo-Quercetum association, as a consequence of the valuable formalized classifications initiated by the Czech School of phytosociology. It is expected that the results will contribute to the development of proper strategies for the conservation of the representative forest habitats, that should be implemented in the future at local or regional level.

\section{Acknowledgements}

This work was supported by CNCSIS-UEFISCDI, project number PN II-RU PD_360/2010. I like to thank Dr. Tudor Stancioiu for his suggestions on the first version of the manuscript and Mrs. Iringo Abrudan for the English correction.

\section{References}

Abrudan IV, Marinescu V, Ionescu O, Ioras F, Horodnic SA, Sestras R (2009). Developments in the Romanian forestry and its linkages with other sectors. Notulae Botanicae Horti Agrobotanici Cluj-Napoca 37(2):14-21

Borza A (1959). The flora and vegetation of Sebes. Valey Ed. Academiei RPR Bucharest (in Romanian).

Botta-Dukát Z, Chytrý M, Hájková P, Havlová M (2005).
Vegetation of lowland wet meadows along a climatic continentality gradient in Central Europe. Preslia 77:89111.

Ciocarlan V (2000). Ilustrated flora of Romania. Pteridophyta et Spermatophyta. Ed. Ceres. Bucharest (in Romanian).

Chytrý M (1994). Xerothermic oak forests in the middle Vah basin and the southern part of the Strazovska Hornatina upland, Slovakia. Scripta-Biology 22-23:121-134

Chytrý M (1997). Thermophilous oak forests in the Czech Republic: Syntaxonomical revision of the Quercetalia pubescenti-petraeae. Folia Geobot Phytotax 32:221-258.

Chytrý M, Horak J (1997). Plant communities of thermophilous oak forests in Moravia. Preslia 68:193-240.

Chytrý M, Tichý L, Holt V, Botta-Dukát Z (2002). Determination of diagnostic species with statistical fidelity measures. J Veg Sci 13:79-90.

Ciosek M (2006). The ladybells Adenophora liliifolia (L.) Besser in forests near Kisielany (Siedlce Upland, E Poland). Biodiv Res Conserv 3-4:324-328.

Ciurchea M (1964). Vegetation aspects in the Boholt Valley (Fagaras dep.). Contributii Botanice 4:249-263 (in Romanian).

Coldea Gh, Miclaus V (1975). Contributions to the study of oak forests in the north-eastern piedmont of Plopis Mountains "Lapis Forest" (Salaj county). Contributii Botanice 15:121127 (in Romanian).

Coldea Gh, Pop A (1996). Phytosociological studies upon the meso-thermophilous oak forests in Transylvania. Stapfia 45:55-64 (in German).

Csürös St, Resmerita I, Csürös-Kaptalan M (1969). Studies of vegetation from Huedin basin. Contributii Botanice 9:211222 (in Romanian).

Danciu M (1972). Phytosociological aspects of sessile oak forests in Baraolt Mountains. Buletinul Universitatii din Brasov, series B, 14:129-134 (in Romanian).

Donita N, Biris IA (2003). Creation of an ecological basis for sustainable forest management in Romania. Analele ICAS 46(1):81-91.

Indreica A (2007). Festuca amethystina in the sessile oak forests from upper basin of Olt River. Contributii Botanice 42:1118.

Ioras F, Abrudan IV, Dautbasic M, Avdibegovic M, Gurean G, Ratnasingam J (2009). Conservation Gains through HCVF Assessments in Bosnia-Herzegovina and Romania. Biodiversity and Conservation 18(13):3395-3406

Gergely I (1962). Contributions to the phytosociological study of the forests from northern Trascau Mountains. Contributii Botanice 3:263-298 (in Romanian).

Hennekens SM, Schaminée JHJ (2001). TURBOVEG, a comprehensive data base management system for vegetation data. J Veg Sci 12:589-591.

Jakucs P (1960). New phytosociological classification of xerothermic oak forests, Quercetea pubescenti-petraeae cl. 
302 nova in Europe. Acta Bot Acad Sci Hung 6(3-4):267-303 (in French).

Libbert W (1933). Vegetation units in the Neumark basin (in German). $2^{\text {nd }}$ Part Verh bot Ver Prov Brandenburg 75:229 348.

Kovacs $\mathrm{Al}$ (1979). The flora and vegetation of Bodoc Mountains. $\mathrm{PhD}$ Thesis, Babes-Bolyai University, Cluj-Napoca (in Romanian)

Kovacs AJ (2004). Syntaxonomical checklist of the plant communities of Szekerland (Eastern Transylvania). Kanitzia 12:75-149.

Matuskiewicz J, Kozlowska A (1991). Phytosociological review of forest communities in Poland - the Quercetalia pubescentis order. Fragmenta Floristica et Geobotanica 36(1):203-256.

McCune B, Grace J, Urban D (2002). Analysis of ecological communities. MjM Software Design. Gleneden Beech, Oregon.

McCune B, Mefford MJ (2006). PC-ORD. Multivariate Analysis of Ecological Data. Version 5.10. MjM Software, Gleneden Beach, Oregon.

Morozova O (2003). Forest vegetation in Nerussa-Desna, Russia: assessment of its nature conservation value. Proc. Natural Forests in the Temperate Zone of Europe-Values and Utilization. International Conference. Carpathian Biosphere Reserve and Swiss Federal Research Institute WSL.

Mráz K (1958). Contribution to the knowledge of the position of Potentillo albae-Quercetum. Archiv für Forstwesen 7(9):703-728 (in German).

Müller Th (1992). Quercetalia pubescenti-petraeae. In: E. Oberdorfer (Ed.). Süddeutsche Pflanzengesellschaften Teil IV. Walder und Gebüsche. Gustav Fischer Verlag (in German).

Neuhäusl R, Neuhäuslová-Novotná Z (1968). Mesophilous and subxerophilous forest associations of middle Bohemia (in German). Folia Geobot Phytotax 3:225-273.

Roleček J (2004). Subcontinental oak forests of Carici fritschiiQuercetum roboris association in Záhorská nížina Lowland
(Slovakia) (in Slovak). Bulletin Slov Bot Spoločn 26:163176.

Roleček J (2005). Vegetation types of dry-mesic oak forests in Slovakia. Preslia 77:241-261.

Roleček J (2007). Vegetation of subcontinental oak forests in Central and Eastern Europe. PhD thesis. Masaryk University. Brno.

Sanda V, Popescu A, Stancu DI (2001). The coenotic structure and ecological characterization of Romanian phytocoenoses. Ed. Conphis. Bucharest (in Romanian).

Sanda V, Vicol I, Stefanut S (2008). The coeno-structural biodiversity of Romanian vegetation. Ed. Ars Docendi. Bucharest (in Romanian).

Soó R (1951). Plant associations of middle Transylvania. I The forest associations. Ann Hist Nat Mus Nation Hung ser nova 1(1):1-71 (in French).

Stancioiu PT, Abrudan IV, Dutca I (2010). The Natura 2000 ecological network and forests in Romania: implications on management and administration. The International Forestry Review 12(1):106-113.

Tichý L (2002). JUICE, software for vegetation classification. J Veg Sci 15:451-453.

Treiber R, Remmert G (1998). Deciduous forest communities of dry, warm sites in the upper Rhine Plain (Department Haut-Rhin, France). Tuexenia 18:21-50 (in German).

Ularu P (1972). Phytosociological studies in sessile oak forests in Persani Mountains. Buletinul Universitatii Brasov, series C, 14:173-186 (in Romanian).

Wallnöfer S (2003). Thermophilous oak forests communities in eastern Austria. Verh Zool-Bot Ges Österreich 140:1-16 (in German).

Wallnöfer S, Mucina L, Grass V (1993). Querco-Fagetea, p. 85236. In: Mucina L , Grabherr G and Wallnöfer S (Eds.). Die Pflanzengesellschften Osterreichs 3, Walder und Gebusche. Gustav Fischer. Jena (in German).

Willner W, Tichý L, Chytrý M (2009). Effects of different fidelity measures and contexts on the determination of diagnostic species. J Veg Sci 20:130-137.

Tab. 2. Potentillo albae-Quercetum petraeae Libbert 1933

\begin{tabular}{|c|c|c|c|c|c|c|c|c|c|c|c|c|c|c|c|c|c|c|c|c|c|c|c|c|c|}
\hline Relevee nr. & 1 & 2 & 3 & 4 & 5 & 6 & 7 & 8 & 9 & 10 & 11 & 12 & 13 & 14 & 15 & 16 & 17 & 18 & 19 & 20 & 21 & 22 & 23 & 24 & 25 \\
\hline Altitude (x $10 \mathrm{~m}$ a.s.1.) & 64 & 62 & 63 & 61 & 62 & 90 & 65 & 59 & 79 & 69 & 66 & 87 & 64 & 59 & 75 & 66 & 74 & 54 & 62 & 63 & 45 & 53 & 55 & 31 & 36 \\
\hline Exposition & $\mathrm{N}$ & $\mathrm{E}$ & $S$ & SE & SW & NW & $\mathrm{W}$ & SE & $E$ & $E$ & $S$ & $\mathrm{~W}$ & $S$ & - & $S$ & $\mathrm{~N}$ & $\mathrm{~W}$ & $S$ & SW & $\mathrm{W}$ & $S$ & - & $\mathrm{W}$ & $E$ & $\mathrm{~W}$ \\
\hline Slope $\left({ }^{\circ}\right)$ & 15 & 5 & 5 & 5 & 5 & 10 & 12 & 5 & 5 & 3 & 10 & 20 & 20 & 0 & 5 & 10 & 20 & 15 & 5 & 5 & 5 & 0 & 2 & 3 & 15 \\
\hline Cover (\%) - tree layer & 50 & 60 & 70 & 75 & 75 & 85 & 70 & 70 & 75 & 65 & 70 & 70 & 60 & 70 & 70 & 65 & 75 & 80 & 60 & 55 & 80 & 70 & 65 & 70 & 70 \\
\hline - shrub layer & 1 & 5 & 5 & 45 & 1 & 3 & 5 & 2 & 1 & 5 & 1 & 3 & 10 & 40 & 5 & 5 & 2 & 1 & 2 & 2 & 5 & 40 & 10 & 30 & 50 \\
\hline - herb layer & 80 & 60 & 90 & 60 & 75 & 80 & 85 & 85 & 85 & 80 & 60 & 60 & 50 & 70 & 65 & 80 & 40 & 50 & 60 & 60 & 60 & 50 & 70 & 40 & 20 \\
\hline \multicolumn{26}{|l|}{ E3 - tree layer } \\
\hline Quercus petraea & 4 & 4 & 5 & 5 & 4 & 5 & 4 & 2 & 5 & 4 & 4 & 4 & 4 & + & 4 & 4 & 5 & 5 & 4 & 3 & 4 & 4 & 4 & 4 & + \\
\hline Quercus robur & . & + & + & . & . & . & . & 4 & . & . & . & . & . & 4 & . & . & . & . & 1 & 2 & . & . & . & . & 1 \\
\hline Quercus cerris & . & . & . & . & . & . & . & + & . & . & . & . & . & . & . & . & . & . & . & . & 2 & . & . & + & 4 \\
\hline \multicolumn{26}{|l|}{ E2 - shrub layer } \\
\hline Carpinus betulus & + & 1 & . & 2 & + & + & + & . & + & + & + & + & 1 & 1 & + & 1 & + & . & . & . & 1 & + & & + & . \\
\hline Corylus avellana & + & + & + & + & + & + & . & + & + & . & + & . & 1 & & . & + & + & . & + & + & . & 2 & & . & \\
\hline
\end{tabular}




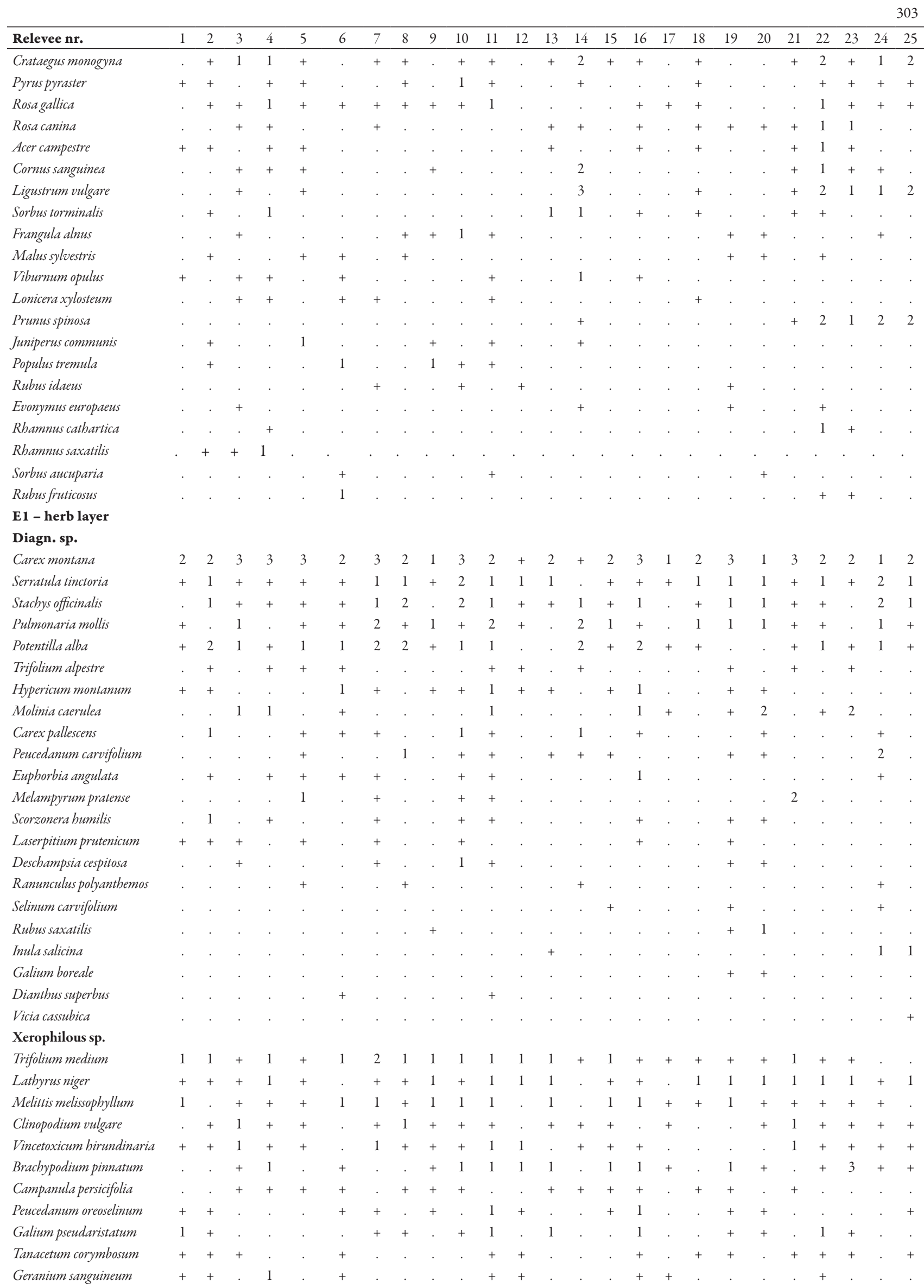


304

\begin{tabular}{|c|c|c|c|c|c|c|c|c|c|c|c|c|c|c|c|c|c|c|c|c|c|c|c|c|c|}
\hline Relevee nr. & 1 & 2 & 3 & 4 & 5 & 6 & 7 & 8 & 9 & 10 & 11 & 12 & 13 & 14 & 15 & 16 & 17 & 18 & 19 & 20 & 21 & 22 & 23 & 24 & 25 \\
\hline Sedum maximum & . & . & + & + & . & . & . & + & . & . & + & + & . & . & & . & + & . & . & . & + & 1 & . & . & . \\
\hline Hierocbloë australis & . & & . & 1 & & + & + & . & 2 & . & 1 & + & . & & & 1 & + & 1 & . & . & & . & . & & \\
\hline Digitalis grandiflora & + & & + & . & & . & + & . & . & & . & 1 & + & & + & . & + & . & + & . & . & . & & & . \\
\hline Carex michelii & & . & + & 1 & + & & . & & . & & 1 & . & & 2 & & & & & & & . & 1 & 1 & . & \\
\hline Euphorbia cyparissias & . & & . & + & & . & & + & & . & + & & . & + & + & . & . & . & . & . & & . & + & & + \\
\hline Peucedanum cervaria & & + & & + & . & & . & . & . & & . & . & & & . & + & & + & . & . & . & + & + & . & . \\
\hline Polygonatum odoratum & . & & . & . & & . & & . & + & . & . & 2 & . & & . & + & . & + & + & . & + & . & . & & . \\
\hline Crepispraemorsa & & & & + & & . & & . & & . & + & & + & & . & + & & . & + & & & & & & + \\
\hline Filipendula vulgaris & . & & . & & & . & & 1 & & + & . & & . & + & . & . & . & . & . & + & & + & + & & + \\
\hline Laserpitium latifolium & & . & & + & . & & . & & + & & + & 1 & & . & + & & & & & . & . & . & & . & \\
\hline Festuca rupicola & . & & . & . & & + & & . & . & . & . & & . & + & + & . & . & . & . & . & + & . & . & & + \\
\hline Primula veris & & . & & & . & & + & & . & & & 1 & & . & & & & & & & + & & & + & \\
\hline Carex caryophyllea & . & & . & . & + & . & & . & . & . & . & & . & + & . & . & + & . & . & . & . & 1 & . & & . \\
\hline Coronilla varia & & . & & + & . & & . & . & . & & & . & + & + & + & & & & & . & . & . & & . & . \\
\hline Anthericum ramosum & . & + & . & 1 & & . & & . & . & . & . & + & . & & . & . & . & . & . & . & & . & . & & + \\
\hline Carex tomentosa & & & & + & & . & & . & & . & + & & . & & . & . & & . & . & & & & & & 1 \\
\hline Carex praecox & . & & . & . & & . & & . & & + & . & & . & & . & . & . & . & . & . & & . & + & & 1 \\
\hline Fragaria viridis & & & & . & . & & . & . & . & & & . & & . & . & & & & . & . & . & + & + & . & + \\
\hline Melampyrum cristatum & . & & . & . & & + & & . & & . & + & + & . & & . & . & . & . & . & . & & . & . & & . \\
\hline \multicolumn{26}{|l|}{ Mesophilous sp. } \\
\hline Mycelis muralis & + & & 1 & . & + & + & + & + & & + & + & & . & & + & + & + & . & . & . & & + & + & + & + \\
\hline Viola reichenbachiana & + & + & 1 & + & 1 & + & & 1 & 1 & + & 1 & & . & + & + & + & + & + & + & . & + & + & + & & . \\
\hline Neottia nidus-avis & + & & . & + & + & + & & . & + & . & . & & + & & + & . & + & . & . & + & & & . & & . \\
\hline Phyteuma tetramerum & + & & + & + & 1 & 1 & + & . & & . & + & & . & + & . & 1 & . & . & 1 & 1 & & & & & . \\
\hline Poa angustifolia & . & & + & + & 2 & . & & 1 & 2 & + & 1 & & . & + & + & . & + & . & . & . & + & 1 & 1 & + & . \\
\hline Platanthera bifolia & + & + & & + & + & + & & . & . & + & + & & . & + & . & + & & + & . & + & + & . & + & . & . \\
\hline Lathyrus vernus & 1 & . & + & + & 1 & + & . & & + & + & + & . & + & . & 1 & + & & + & + & + & . & + & & + & \\
\hline Fagus sylvatica (juv.) & 1 & + & + & 1 & + & . & 1 & 1 & . & 1 & 1 & . & 1 & + & 1 & 1 & . & . & . & . & . & . & . & . & . \\
\hline Galium schultesii & & & 2 & . & & . & & 1 & 1 & & . & & . & + & 1 & . & & + & . & . & + & . & & & . \\
\hline Pulmonaria officinalis & + & + & . & + & + & . & & + & & 1 & 1 & & . & 1 & + & + & . & . & . & . & & . & . & & . \\
\hline Melampyrum bihariense & 2 & + & 2 & . & . & & . & 2 & 2 & & & . & & . & 1 & 1 & & & + & + & . & + & 1 & . & \\
\hline Lysimachia nummularia & . & & 2 & . & + & . & & 2 & & . & + & & . & 1 & . & . & . & . & . & . & + & . & . & 2 & + \\
\hline Dryopteris filix-mas & + & . & + & & + & & + & & + & + & + & . & & . & & + & & & & & . & & & . & \\
\hline Melica nutans & . & & + & . & + & . & & . & & . & . & & . & & . & + & . & . & 1 & + & & 1 & + & & . \\
\hline Athyrium filix-femina & + & . & + & & . & & + & & . & & + & . & & . & & + & & & & & . & & & . & \\
\hline Moehringia trinervia & . & & + & & & . & & . & & + & . & & . & & . & . & . & . & 1 & + & & & . & & . \\
\hline Lilium martagon & & & & + & & + & & . & & . & . & + & . & & . & + & . & . & . & & & & & & . \\
\hline Helleborus purpurascens & . & & . & . & + & . & & . & & . & . & & . & 1 & 1 & 1 & . & . & . & . & & . & . & & . \\
\hline Stellaria holostea & & & & . & & . & & . & . & & . & & . & & 1 & . & & . & . & . & . & 1 & + & . & . \\
\hline Listera ovata & + & & . & . & & + & & . & & . & . & & . & & & . & . & . & . & + & & . & . & & . \\
\hline \multicolumn{26}{|l|}{ Acidophilous sp. } \\
\hline Luzula luzuloides & 1 & & 1 & . & 1 & 2 & + & . & 2 & 1 & + & 1 & 1 & + & 1 & + & 2 & 1 & 1 & + & 1 & . & & & . \\
\hline Veronica officinalis & . & + & + & & + & + & + & + & + & + & + & & . & & + & . & . & . & + & + & + & + & . & & . \\
\hline Calamagrostis arundinacea & 1 & 2 & + & 1 & . & 2 & + & . & 1 & & 2 & 1 & 2 & . & 2 & 2 & & 1 & + & . & . & 2 & 1 & + & \\
\hline Hieracium murorum & + & & . & . & & + & & . & 1 & . & 1 & & 1 & & 1 & . & + & + & . & . & & . & . & & . \\
\hline Genista tinctoria & & + & 1 & & . & + & + & + & . & & + & . & & + & + & & + & & & & + & + & + & . & + \\
\hline Maianthemum bifolium & + & & + & 1 & + & 1 & & . & + & . & + & & . & & . & + & + & . & . & . & & . & . & & . \\
\hline Pteridium aquilinum & 1 & . & + & & . & + & 1 & & . & 1 & + & . & + & . & & 2 & 1 & & & & . & & & . & \\
\hline Lychnis viscaria & . & & . & . & & . & & . & & . & . & + & + & & + & . & + & . & . & . & & . & . & & + \\
\hline Pyrola rotundifolia & + & & & & & 1 & + & . & + & . & . & & . & & . & . & . & . & . & & & & & & . \\
\hline Orthilia secunda & . & & . & . & & + & & . & & . & 1 & & . & & & + & + & . & . & . & & . & . & & \\
\hline Vaccinium myrtillus & & & & . & & 1 & . & . & 1 & & . & . & . & & & . & + & & . & . & . & . & & . & . \\
\hline Vaccinium vitis-idaea & . & & . & . & & 1 & & . & 1 & . & . & & . & & & . & 1 & . & . & . & & . & . & & \\
\hline \multicolumn{26}{|l|}{ Variae } \\
\hline Quercus petraea (juv.) & 1 & 1 & + & 1 & 1 & 1 & 1 & 1 & 2 & 2 & 2 & + & 1 & & 1 & 2 & 1 & 1 & 1 & 1 & 2 & 2 & 2 & + & + \\
\hline Fragaria vesca & 1 & + & 2 & 1 & 1 & 2 & 1 & 2 & 1 & 2 & 1 & 1 & 1 & 1 & 1 & 1 & + & 1 & 1 & + & + & 1 & 1 & 1 & \\
\hline Veronica chamaedrys & 1 & + & + & + & 1 & 1 & 1 & 1 & 2 & + & 1 & 1 & + & + & 1 & + & + & + & 1 & 1 & + & + & + & & \\
\hline
\end{tabular}


305

\begin{tabular}{|c|c|c|c|c|c|c|c|c|c|c|c|c|c|c|c|c|c|c|c|c|c|c|c|c|c|}
\hline Relevee nr. & 1 & 2 & 3 & 4 & 5 & 6 & 7 & 8 & 9 & 10 & 11 & 12 & 13 & 14 & 15 & 16 & 17 & 18 & 19 & 20 & 21 & 22 & 23 & 24 & 25 \\
\hline Dactylis glomerata & 1 & + & 1 & + & + & . & 1 & 1 & . & 1 & 1 & . & 1 & 1 & + & + & . & + & 1 & + & 1 & 2 & 2 & + & . \\
\hline Cruciata glabra & + & + & + & + & 1 & 2 & + & 1 & 1 & 1 & 1 & 1 & + & 1 & 1 & + & 1 & 1 & 1 & + & 2 & 1 & + & + & + \\
\hline Poa nemoralis & . & 1 & + & + & + & 1 & . & . & . & + & . & 2 & + & + & + & + & + & . & 1 & 1 & . & + & . & . & + \\
\hline Ajuga reptans & 1 & 1 & 1 & 1 & 1 & + & 1 & 2 & 1 & 1 & + & . & + & + & 1 & + & + & + & 1 & 1 & 1 & + & + & . & . \\
\hline Luzula pilosa & + & . & + & . & + & + & 1 & . & . & 1 & 1 & . & . & + & . & + & . & . & + & + & . & . & . & . & . \\
\hline Iris ruthenica & 1 & . & . & 1 & . & 1 & . & . & 2 & 1 & 1 & 1 & . & . & + & + & 1 & 1 & . & . & . & 1 & 2 & . & . \\
\hline Potentilla erecta & + & + & . & . & + & + & + & . & . & 1 & 1 & . & + & + & . & 1 & + & . & + & + & . & . & . & . & . \\
\hline Ranunculus auricomus & + & . & + & + & + & 1 & + & + & + & . & + & . & . & + & + & 1 & . & + & 1 & + & + & + & . & . & . \\
\hline Scrophularia nodosa & + & + & + & . & + & . & . & . & . & . & + & . & . & . & . & + & . & . & 1 & + & . & . & . & . & . \\
\hline Sanicula europaea & 1 & + & . & + & + & . & 2 & + & . & 2 & 1 & . & . & + & + & 1 & . & . & + & . & + & . & . & . & . \\
\hline Symphytum tuberosum & + & . & + & 1 & 1 & 2 & 1 & + & + & . & + & . & . & 2 & + & + & . & + & 1 & + & . & . & + & . & . \\
\hline Chamaecytisus hirsutus & + & + & + & 1 & + & + & + & 1 & 1 & + & + & + & . & + & + & + & . & + & + & . & . & . & + & . & . \\
\hline Solidago virgaurea & + & . & . & . & . & + & + & . & + & . & 1 & . & + & . & + & + & . & + & + & . & . & + & . & . & . \\
\hline Festuca heterophylla & 1 & . & . & . & + & + & + & . & + & + & 1 & 2 & . & . & + & + & 1 & + & + & . & . & 1 & + & + & . \\
\hline Geum urbanum & . & . & + & + & + & . & + & + & . & + & . & . & . & 1 & . & + & . & . & 1 & + & + & + & + & + & . \\
\hline Hieracium sabaudum & + & + & . & + & + & . & . & + & + & + & + & . & 1 & + & + & . & . & + & . & + & 1 & + & . & + & 1 \\
\hline Convallaria majalis & + & + & 1 & . & . & . & + & . & + & . & . & 1 & . & + & 1 & 1 & . & + & 1 & 2 & . & + & . & . & . \\
\hline Vicia sepium & . & . & 1 & + & + & + & + & 1 & + & + & 1 & . & . & + & + & + & + & . & + & . & . & . & . & . & . \\
\hline Festuca amethystina & . & . & . & . & . & + & + & . & 2 & + & + & + & 1 & . & . & + & . & . & . & . & . & . & . & . & . \\
\hline Succisa pratensis & + & + & . & . & . & . & 1 & + & . & + & 1 & . & . & . & . & + & . & . & + & . & . & . & . & . & . \\
\hline Hieracium umbellatum & . & . & + & . & . & + & 1 & + & + & 1 & 1 & + & . & . & . & 1 & + & . & + & . & + & + & + & . & . \\
\hline Achillea distans & . & . & + & + & + & + & . & . & 1 & . & + & + & + & . & 1 & . & 1 & . & . & . & . & . & . & . & . \\
\hline Anemone nemorosa & . & + & . & 1 & 1 & + & . & . & . & . & . & . & . & + & . & + & . & . & 1 & . & . & . & . & + & . \\
\hline Lapsana communis & . & . & + & . & + & . & . & + & . & . & . & . & . & + & . & . & . & . & . & . & . & . & . & . & + \\
\hline Campanulaglomerata & + & + & . & . & + & . & . & . & . & + & + & + & . & + & . & + & . & . & . & . & . & . & . & + & . \\
\hline Campanula rapunculoides & . & . & . & + & + & . & . & + & 1 & . & . & . & 1 & . & + & . & . & + & . & . & 1 & . & . & . & + \\
\hline Brachypodium sylvaticum & + & . & 1 & . & + & . & + & + & . & . & 1 & . & . & 2 & . & . & . & . & . & . & 1 & + & . & . & . \\
\hline Avenula praeusta & . & + & . & + & . & 1 & + & + & 1 & + & + & . & . & . & + & . & + & . & . & . & . & . & + & . & . \\
\hline Astrantia major & 1 & . & . & + & . & . & 2 & . & . & + & . & . & . & . & 1 & 2 & . & . & + & 1 & . & . & . & . & . \\
\hline Carex umbrosa & . & . & + & . & . & . & 1 & . & . & 1 & + & . & . & . & . & + & . & . & . & + & . & . & . & . & . \\
\hline Cerasus avium & . & . & 1 & . & . & . & . & . & . & . & + & . & . & . & . & . & . & + & . & . & + & + & . & . & . \\
\hline Valeriana wallrothii & . & . & + & . & . & . & + & + & . & . & . & + & . & 1 & . & . & . & + & . & . & . & . & . & . & . \\
\hline Trollius europaeus & + & . & . & . & . & . & . & . & . & . & . & . & . & . & . & + & . & . & + & + & . & . & . & . & . \\
\hline Pimpinella saxifraga & . & . & . & + & . & . & . & + & . & . & . & . & + & . & . & . & . & . & . & . & . & . & + & . & . \\
\hline Crocus banaticus & + & . & . & + & 1 & . & . & . & . & . & . & . & . & 1 & . & + & . & . & . & . & . & . & . & . & . \\
\hline Lysimachia vulgaris & . & + & . & . & . & . & . & 1 & . & . & . & . & . & 1 & . & . & . & . & + & 1 & . & . & . & . & . \\
\hline Agrimonia eupatoria & . & . & . & + & . & . & . & + & . & + & . & . & . & . & . & . & . & . & . & . & . & + & . & . & . \\
\hline Tilia cordata (juv.) & . & . & . & . & . & + & . & + & . & . & . & 1 & . & . & . & . & . & + & . & . & . & + & . & . & . \\
\hline Bromus ramosus & . & . & 1 & . & + & + & . & . & . & . & + & . & . & . & . & + & . & . & . & . & . & . & . & . & . \\
\hline Galium aparine & . & . & . & . & + & + & . & . & . & . & . & . & . & . & . & . & . & . & + & + & . & . & . & . & + \\
\hline Gentiana asclepiadea & + & . & + & . & . & + & . & . & . & . & . & . & . & . & + & . & . & . & + & . & . & . & . & . & . \\
\hline Hypericum perforatum & . & . & + & . & + & . & . & . & . & . & . & . & . & + & . & . & + & . & . & . & + & . & + & . & . \\
\hline Hieracium lachenalii & + & . & . & . & + & + & . & + & . & . & + & . & . & . & . & . & . & . & . & . & . & . & . & . & . \\
\hline Agrostis capillaris & . & . & . & . & $\cdot$ & . & . & 2 & . & 1 & + & . & . & + & . & . & . & . & . & . & . & . & . & . & . \\
\hline Euphorbia amygdaloides & . & . & . & . & 1 & . & . & 1 & . & . & . & . & . & . & 1 & + & . & . & . & . & . & + & . & . & . \\
\hline Epilobium montanum & . & . & . & . & . & + & + & . & . & . & + & . & . & . & . & + & . & . & . & . & . & . & . & . & . \\
\hline Myosotis scorpioides & . & . & . & . & + & + & . & . & . & . & + & . & . & . & . & . & . & . & . & . & . & . & . & . & . \\
\hline Festuca rubra & . & . & + & . & + & + & . & 1 & . & . & . & . & . & + & . & . & + & . & + & + & . & . & . & + & . \\
\hline Festuca gigantea & + & . & 2 & + & + & . & + & . & . & + & + & . & . & + & . & + & . & . & . & . & . & . & . & . & . \\
\hline Thalictrum aquilegiifolium & . & . & + & . & . & . & . & . & . & . & + & . & . & . & . & + & . & . & + & . & . & . & . & . & . \\
\hline Adenophora liliifolia & + & . & . & . & . & . & . & . & . & . & . & . & . & . & . & . & . & . & + & + & . & . & . & . & . \\
\hline Lysimachia punctata & . & . & + & . & + & . & . & . & . & + & . & . & . & . & . & . & . & . & . & . & . & . & . & . & . \\
\hline Quercus robur (juv.) & . & + & . & . & . & . & . & . & . & . & . & . & . & 1 & . & . & . & . & . & + & . & . & . & . & . \\
\hline Fraxinus excelsior (juv.) & . & + & . & . & . & . & . & + & . & + & . & . & . & . & . & . & . & . & . & . & . & . & . & . & . \\
\hline Festuca drymeja & . & . & . & . & + & . & . & . & . & + & . & . & . & 1 & . & . & . & . & . & . & . & . & . & . & . \\
\hline Salviaglutinosa & . & . & . & . & . & . & . & + & . & . & . & . & + & . & . & . & . & . & . & + & . & . & . & . & . \\
\hline Angelica sylvestris & . & . & + & . & . & . & + & . & . & . & . & . & . & . & . & . & . & . & . & + & . & . & . & . & . \\
\hline
\end{tabular}




\begin{tabular}{|c|c|c|c|c|c|c|c|c|c|c|c|c|c|c|c|c|c|c|c|c|c|c|c|c|c|}
\hline Relevee nr. & 1 & 2 & 3 & 4 & 5 & 6 & 7 & 8 & 9 & 10 & 11 & 12 & 13 & 14 & 15 & 16 & 17 & 18 & 19 & 20 & 21 & 22 & 23 & 24 & 25 \\
\hline Cephalanthera longifolia & . & . & . & . & . & . & + & + & . & . & + & . & . & . & . & . & . & . & . & . & . & . & . & . & . \\
\hline Hieracium cymosum & . & . & . & . & 1 & . & . & . & . & 1 & . & . & + & . & . & . & . & . & . & . & . & . & . & . & . \\
\hline Dactylorhiza maculata & + & . & . & . & . & . & . & . & . & . & . & . & . & . & . & + & . & . & . & + & . & . & . & . & . \\
\hline Calamagrostis epigeios & . & . & . & + & . & . & . & . & . & . & . & . & . & . & . & . & . & . & . & . & . & 1 & . & . & 1 \\
\hline Astragalus glycyphyllos & . & . & . & + & . & . & . & . & . & . & . & . & . & . & . & . & + & . & . & . & . & . & . & + & . \\
\hline Carex spicata & . & . & . & . & + & . & . & . & . & . & . & . & . & . & . & . & . & . & . & + & . & . & . & + & . \\
\hline Torilis japonica & . & . & + & . & + & . & . & . & . & . & . & . & . & . & . & . & . & . & . & . & . & . & + & . & . \\
\hline Campanula patula & . & . & + & . & . & + & . & + & . & . & . & . & . & . & . & . & . & . & . & . & . & . & . & . & . \\
\hline Taraxacum officinale & . & . & + & + & + & . & . & . & . & . & . & . & . & . & . & . & . & . & . & . & . & . & . & . & . \\
\hline \multicolumn{26}{|l|}{ E0 - Moss layer } \\
\hline Atrichum undulatum & + & + & + & . & + & . & + & . & . & + & + & . & . & . & . & . & . & . & . & . & . & . & . & . & . \\
\hline Polytrichum formosum & . & + & . & . & . & + & . & . & . & . & + & . & + & . & . & . & . & . & . & . & . & . & . & . & . \\
\hline
\end{tabular}

Other species: Eurhynchium striatum 1: +; Lamium galeobdolon 1: +, 16: +; Lathyrus transsilvanicus 1: 1, 16: 2; Inula germanica 2: +; Padus avium 2: +, 7: +; Plagiomnium undulatum 2: +, 3: +; Aegopodium podagraria 3: 1; Carex sylvatica 3: +, 21: +; Daphne mezereum 3: +, 9: +; Epilobium roseum 3: +, 20: +; Galeopsis tetrahit 3: +; Geranium robertianum 3: +; Hieracium racemosum 3: +; Inula britannica 3: +; Milium effusum 3: 1; Polygonatum multiflorum 3: +; Rubus nessensis 3: 1, 7: +; Trifolium aureum 3: +; Urtica dioica 3: +; Veratrum album 3: +, 20: +; Vicia cracca 3: +, 20: +; Acer campestre 4: +; Acer pseudoplatanus 4: +, 18: +; Campanula cervicaria 4: +; Cytisus nigricans $4:+, 21: 1$; Evonymus verrucosus $4:+$; Ferulago sylvatica 4: 1, 12: +; Galium mollugo 4: +; Heracleum sphondylium 4: +, 16: +; Hypochaeris maculata 4: +, 18: +; Rosa pimpinellifolia 4: +; Viburnum lantana 4: +, 22: 1; Achillea millefolium 5: +, 8: +; Anthoxanthum odoratum 5: +, 6: +; Erigeron annuus 5: +; Glechoma hederacea 5: +; Hypochaeris radicata 5: +; Prunella vulgaris 5: +; Hieracium aurantiacum 6: +; Hieracium baubinit 6: +; Picea abies (juv.) 6: +; Rosa tomentosa 6: +; Trifolium pannonicum 6: +; Veronica urticifolia 6: +; Viola odorata 6: +; Aconitum variegatum 7: +, 15: +; Circaea lutetiana 7: +; Galium glaucum 7: +; Hepatica transsilvanica 7: +; Hieracium caespitosum 7: +, 11: +; Centaurea indurata 8: +; Clematis recta 8: +, 24: +; Lotus corniculatus 8: +, 10: +; Stellaria graminea 8: +, 14: +; Carex pilosa 9: 1; Dryopteris carthusiana 10: 1, 16: +; Viola canina 10: +; Dicranum scoparium 11: +; Hypnum cupressiforme 11: +, 13: +; Lathyrus pratensis 11: +; Salix caprea 11: +; Cardaminopsis arenosa 12: +; Dianthus armeria 12: +; Pinus sylvestris 12: +; Ranunculus oreophilus 12: 1; Rosa pendulina 12: +; Seseli libanotis 12: 1; Silene nutans 12: +, 13: +; Silene vulgaris 12: 1; Thesium linophyllon 12: +; Campanula trachelium 13: +; Cephalanthera rubra 13: +; Dentaria bulbifera 13: +, 15: +; Epipactis helleborine 13: +; Hieracium dentatum 13: +; Briza media 14: +; Galium odoratum 14: +; Galium verum 14: +; Hypericum hirsutum 14: +; Lychnis flos-cuculi 14: +, 20: +; Rubus caesius 14: +; Rumex acetosella 14: +; Polypodium vulgare 15: +; Melica picta 16: +; Acer tataricum 18: +, 25: +; Carex digitata 18: 1; Cornus mas 18: +, 21: +; Fraxinus ornus 18: +, 21: +; Polygonatum latifolium 18: +; Dryopteris dilatata 19: +; Myosotis sylvatica 20: +; Asarum europaeum 21: +; Clematis vitalba 21: +, 22: +; Galeopsis bifida 21: +; Lathyrus hallersteinii 21: +, 22: +; Potentilla micrantha 21: +; Quercus cerris (juv.) 21: +; Rubus canescens 21: +; Valeriana officinalis 21: +; Inula hirta 22: 1, 25: +; Iris graminea 22: +; Polygonum dumetorum 22: +, 25: +; Seseli annuum 24: +; Veratrum nigrum 24: +; Viola alba 24: +; Ajuga genevensis 25: +; Alliaria petiolata 25: +; Dictamnus albus 25: +; Euphorbia esula 25: +; Lithospermum purpureocaeruleum 25: 1; Phleum montanum 25: +; Rosa arvensis 25: +; Silene italica ssp. nemoralis 25: +; Solanum dulcamara 25: +; Stachys recta 25: +; Ulmus minor 25: +; Verbascum chaixii 25: + .

Place of relevees: 1, 2 - Doboseni; 3 - Dobolii; 4 - Racosul de Sus; 5 - Haghig; 6 - Belani, 7, 8, 10, 11 - Biborteni; 9 Petriceni; 12 - Plaiesi; 13 - Hatod; 14 - Aita; 15 - Malnas; 16 - Varghis; 17 - Lemnia; 18 - Cheile Turzii; 19, 20 - Herculian; 21 - Hateg; 22, 23 - Cluj-Napoca; 24, 25 - Racas. 